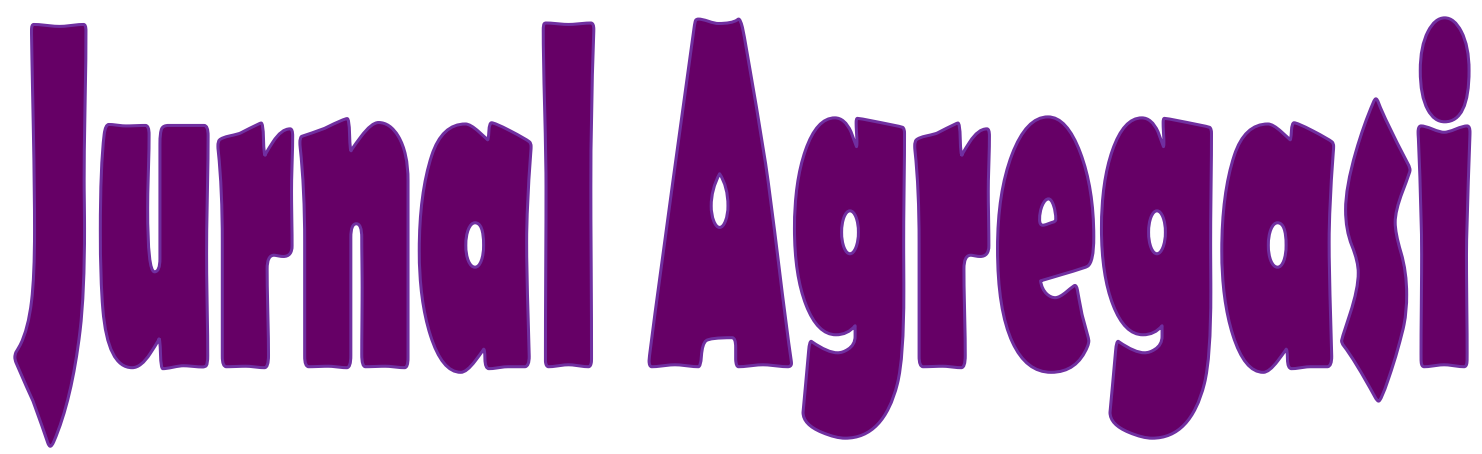

Aksi Reformasi Government dalam Demokrasi

Volume 6 / Nomor 1 / Tahun 2018 / Hal. 1 - 125

Etika Otonomi Daerah Dalam Perspektif Filsafat Pendidikan Fatmawati

Peranan Aparatur Pusat Penelitian dan Pengembangan Daya Air (Puslitbang SDA) dalam Meningkatkan Kualitas Pelayanan Publik Melalui Sistem Informasi Geografis Bidang Sumber Daya Air (SIGSDA) Henri Prianto Sinurat

Revitalisasi Pembangunan Pendidikan Melalui Pendekatan Komunikasi Pendidikan Iwan Koswara

Monitoring dan Evaluasi Pemanfaatan Dana Keistimewaan Daerah Istimewa Yogyakarta Tahun 2013-2017 Laksmi Nurita Tanjung, Dyah Mutiarin dan Eko Priyo Purnomo

Mekanisme Lembaga Adat Melayu Riau dalam Melestarikan Wisata Budaya di Provinsi Riau M.Zainuddin

Implementasi Fungsi Artikulasi dan Agregasi PKS Kota Bandung pada Pemilu 2009 Olih Solihin 


\section{JURNAL AGREGASI}

Merupakan Jurnal Ilmiah berkala yang diterbitkan oleh Program Studi Ilmu Pemerintahan FISIP Unikom. Jurnal ini memuat berbagai hasil penelitian, konsep atau gagasan pemikiran yang terkait dengan reformasi pemerintahan.

\section{DEWAN REDAKSI}

\section{Pembina :}

\section{Dekan FISIP Unikom}

Prof. Dr. Samugyo Ibnu Redjo, Drs., MA.

Penanggung jawab :

Kaprodi Ilmu Pemerintahan Unikom

Dr. Dewi Kurniasih, S.IP., M.Si.

\section{Ketua :}

Nia Karniawati, S.IP.,M.Si.

\section{Mitra Bestari :}

Prof. Dr. Samugyo Ibnu Redjo, Drs.,MA

Prof. Dr. H. Utang Suwaryo, Drs., MA.

Prof. Dr. Cecep Darmawan, S.IP., M.Si.

\section{Tim Editing :}

Dr. Poni Sukaesih K, S.IP.,M.Si.

Tatik Rohmawati, S.IP.,M.Si.

Tatik Fidowaty, S.IP.,M.Si.

Rino Adibowo, S.IP.,M.I.POL

\section{Sekretariat :}

Airinawati, A.Md.

\section{Alamat Redaksi :}

Prodi Ilmu Pemerintahan Unikom

Jl. Dipati Ukur 112-114 Bandung 40132

Telp. 022.2533676 Fax. 022.2506577

OJS : http://ojs.unikom.ac.id/index.php/agregasi

Web : http://jurnalagregasi.ip.unikom.ac.id

Email : jurnalagregasi@email.unikom.ac.id 


\section{KATA PENGANTAR}

Ass. Wr.Wb.

Alhamdulillah, Puji dan Syukur Kita Panjatkan kehadirat Illahi Robbi, atas berkah dan rahmatNya, Jurnal Agregasi Volume 6 Nomor 1 Tahun 2018 dapat kami terbitkan. Jurnal ini merupakan karya ilmiah dari Dosen Ilmu Pemerintahan FISIP Unikom dan Kontributor lain di luar lingkungan Ilmu Pemerintahan FISIP Unikom yang terdiri dari para dosen, pakar maupun praktisi di bidang Pemerintahan.

Dalam Jurnal Agregasi Volume 6 Nomor 1 ini terdapat enam tulisan. Tulisan tersebut merupakan karya ilmiah dari Fatmawati dari STISIP Syamsul Ulum Sukabumi, Henri Prianto Sinurat dari PKP2A IV LAN Banda Aceh, Iwan Koswara dari Unpad Bandung, Laksmi Nurita Tanjung, dkk dari UMY, M.Zainuddin dari Universitas Abdurrab Pekanbaru dan Olih Solihin dari Unikom Bandung. Kepada yang telah berkontibusi memberikan tulisan kami haturkan banyak terima kasih.

Besar harapan kami, karya ilmiah yang terdapat dalam jurnal ini dapat memberikan banyak manfaatnya. Sekian dan terima kasih.

Wss. Wr. Wb.

Bandung, Mei 2018 


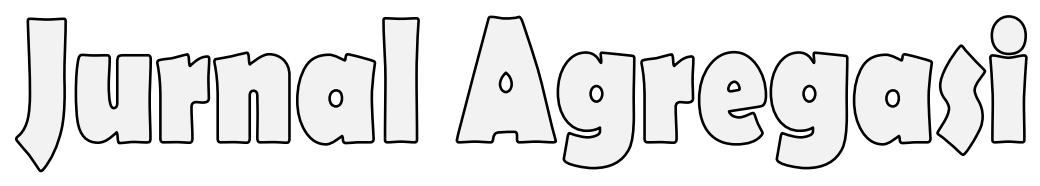

\section{Aksi Reformasi Government dalam Demokrasi \\ e-ISSN: 2579-3047/p-ISSN: 2337-5299/ Vol.6/No.1/Th.2018/Hal.1-125}

\section{DEWAN REDAKSI \\ KATA PENGANTAR \\ DAFTAR ISI}

\section{DAFTAR ISI}

Etika Otonomi Daerah Dalam Perspektif Filsafat Pendidikan

Oleh:

Fatmawati

Peranan Aparatur Pusat Penelitian dan Pengembangan Daya Air

(Puslitbang SDA) dalam Meningkatkan Kualitas Pelayanan Publik Melalui Sistem Informasi Geografis Bidang Sumber Daya Air (SIGSDA)

Oleh:

Henri Prianto Sinurat

Revitalisasi Pembangunan Pendidikan Melalui

Pendekatan Komunikasi Pendidikan

Oleh:

Iwan Koswara

Monitoring dan Evaluasi Pemanfaatan Dana Keistimewaan Daerah

$60-91$

Istimewa Yogyakarta Tahun 2013-2017

Oleh:

Laksmi Nurita Tanjung, Dyah Mutiarin dan Eko Priyo Purnomo

Mekanisme Lembaga Adat Melayu Riau dalam Melestarikan Wisata Budaya di Provinsi Riau.

Oleh:

M.Zainuddin

Implementasi Fungsi Artikulasi dan Agregasi PKS Kota Bandung pada Pemilu 2009.

Oleh:

Olih Solihin 


\title{
REVITALISASI PEMBANGUNAN PENDIDIKAN MELALUI PENDEKATAN KOMUNIKASI PENDIDIKAN
}

\author{
Iwan Koswara ${ }^{1}$ \\ iwankoswara17@gmail.com
}

\begin{abstract}
ABSTRAK
Pendidikan merupakan salah satu penentu kemajuan bangsa dan pembentuk para National Builders yang berkompetisi secara global, hal ini dikarenakan pendidikan mempunyai peranan dalam meningkatkan kualitas manusia sebagai sumber daya pembangunan dan titik sentral dalam upaya keberhasilan pembangunan tersebut. Pembangunan pendidikan diarahkan untuk menghasilkan insan Indonesia cerdas dan kompetitif melalui peningkatan ketersediaan, keterjangkauan, kualitas, relevansi, kesetaraan, dan kepastian memperoleh layanan pendidikan secara merata. Oleh karenanya, melalui komunikasi pendidikan proses revitalisasi pembangunan pendidikan penting dilakukan, untuk membangun strategi maupun program-program pendidikan yang dapat mendukung terhadap peningkatan mutu pendidikan.
\end{abstract}

Kata Kunci : Revitalisasi, Pembangunan Pendidikan, Komunikasi Pendidikan

\section{PENDAHULUAN}

Hakikat Pembangunan adalah pembangunan manusia Indonesia seutuhnya dan pembangunan seluruh masyarakat Indonesia. Dengan kata lain, manusia Indonesia seutuhnya adalah titik sentral dari pembangunan nasional, di mana manusia Indonesia itu sekaligus subyek dan obyek pembangunan. Tilaar (1990). Salah satu aspek penting dalam mencapai pembangunan tersebut adalah Pendidikan. Undang-Undang Dasar Negara Republik Indonesia Tahun 1945 mengamanatkan Pemerintah mengusahakan dan menyelenggarakan satu sistem pendidikan nasional yang meningkatkan keimanan dan ketakwaan kepada Tuhan Yang Maha Esa serta akhlak mulia dalam rangka mencerdaskan kehidupan bangsa. Dan upaya pemerintah membentuk satu sistem pendidikan nasional yang bernafaskan nilai-nilai Undang-undang telah di manifestasikan ke dalam implementasi Undang-Undang No. 20 Tahun 2003 tentang Sistem Pendidikan Nasional. Di dalamnya, ada kewajiban untuk menyelenggarakan suasana belajar dan proses pembelajaran dimana peserta didik terlibat secara aktif mengembangkan

\footnotetext{
${ }^{1}$ Dosen Fikom Unpad Bandung
} 
potensi dirinya untuk memiliki kekuatan spiritual keagamaan, pengendalian diri, kepribadiaan, kecerdasan, akhlak mulia, serta keterampilan yang diperlukan dirinya, masyarakat, bangsa, dan Negara. Oleh karena itu, seharusnya pendidikan di Indonesia diarahkan kepada pembentukan manusia yang utuh guna menciptakan pribadi yang unggul secara intelektual (IQ), emosional $(E Q)$ dan Spiritual $(S Q)$.

Dunia pendidikan adalah sarana manusia untuk menuju suatu perubahan. Pendidikan merupakan alat yang ampuh untuk melakukan sebuah perubahan. Peranan pendidikan dalam masyarakat memiliki peranan yang sangat vital, karena tanpa pendidikan sebuah bangsa atau masyarakat tidak akan merasakan kemajuan (Radjagukguk dan Sriwartini, $2016: 52$ )

Pendidikan merupakan salah satu ujung tombak dalam menunjang pembangunan suatu bangsa. Pendidikan merupakan salah satu penentu kemajuan suatu bangsa, hal ini dikarenakan pendidikan mempunyai peranan dalam meningkatkan kualitas manusia sebagai sumberdaya pembangunan. Pendidikan merupakan sesuatu yang sangat vital bagi pembentukan karakter anak bangsa. Bangsa yang besar adalah bangsa yang mampu melahirkan generasi intelektual yang memiliki pengaruh besar terhadap kemajuan bangsanya.

Pendidikan adalah kehidupan, untuk itu kegiatan belajar harus dapat membekali peserta didik dengan kecakapan hidup (life skill atau life competency) yang sesuai dengan lingkungan kehidupan dan kebutuhan.

Perlunya perubahan yang mendasar dalam sistem pendidikan nasional kita, juga pernah dilontarkan beberapa pihak yang memandang sistem pendidikan nasional kita saat ini sudah tidak efektif, tidak mampu lagi memberikan bekal, serta tidak dapat mempersiapkan peserta didik untuk bisa bersaing dengan bangsabangsa lain di dunia. Winoto (2004: 196).

Pembangunan Pendidikan; Merupakan salah satu bidang garapan dalam pengembangan sumber daya manusia. Pendidikan pada hakekatnya merupakan bentuk yang paling esensial dalam kehidupan manusia. Pendidikan merupakan salah satu penentu kemajuan suatu bangsa, hal ini dikarenakan pendidikan mempunyai peranan dalam meningkatkan kualitas manusia sebagai sumber daya pembangunan. Di dalam Pembangunan berkelanjutan (SDGs), yang dicanangkan UNESCO, Pendidikan adalah salah satu program pembangunan yang terus 
menerus dilaksanakan, karena pada dasarnya fungsi pendidikan akan tetap abadi dalam bentuk kehidupan sosial. Pendidikan merupakan kebutuhan paling asasi bagi semua orang karena masyarakat yang berpendidikan setidaknya dapat mewujudkan tiga hal, yaitu : Pertama, dapat membebaskan dirinya dari kebodohan dan keterbelakangan. Kedua, mampu berpartisipasi dalam proses politik untuk mewujudkan masyarakat yang demokratis dan ketiga, memiliki kemampuan untuk membebaskan diri dari kemiskinan. Bagi sebagian besar orang miskin, pendidikan merupakan salah satu alat mobilitas vertikal yang paling penting. Ketika modal yang lain tidak mereka miliki, terutama modal berupa uang atau barang, hanya dengan modal pendidikanlah mereka dapat berkompetisi untuk mendapatkan kesempatan memperoleh penghidupan yang lebih baik di masa depan (Sulistyastuti, 2007). Pembangunan pendidikan tidak terlepas dari aspek komunikasi pendidikan sebagai langkah awal untuk mensukseskan program-program pendidikan yang berkelanjutan.

Sejalan dengan paparan di atas Roger dan Shoemaker (dalam Nasution, 2009 : 28) mengatakan bahwa pembangunan merupakan suatu jenis perubahan sosial di mana ide-ide baru diperkenalkan kepada suatu sistem sosial untuk menghasilkan pendapatan perkapita dan tingkat kehidupan yang lebih tinggi melalui metode produksi yang lebih modern dan organisasi sosial yang lebih baik. Pembangunan adalah modernisasi pada tingkat sistem sosial. Dalam pembangunan tersebut proses dalam aktivitasnya lekat dengan komunikasi. Proses komunikasi tersebut biasanya menyangkut langkah-langkah seperti identifikasi penataan institusional, perumusan tujuan, identifikasi waktu dan jangka waktu, pemeliharaan saluran, keputusan tentang gaya, teknik dan misi komunikasi, penataan uji coba, monitoring, dan evaluasi.

Sebagai wujud penting dari pembangunan pendidikan ini adalah Komunikasi Pendidikan; yaitu aspek komunikasi dalam dunia pendidikan, atau komunikasi yang terjadi pada bidang pendidikan. Dengan begitu maka faktor pendidikanlah yang menjadi inti pembicaraan, sedangkan komunikasinya lebih merupakan aspek pandang saja, atau "alat" saja. Disebut alat di sini karena fungsinya yang bisa diupayakan untuk membantu memecahkan masalah-masalah pendidikan. Komunikasi dalam pendidikan merupakan unsur yang sangat penting 
kedudukannya. Bahkan ia sangat besar peranannya dalam menentukan keberhasilan pendidikan yang bersangkutan. Orang sering berkata bahwa tinggi rendahnya suatu capaian mutu pendidikan dipengaruhi pula oleh faktor komunikasi ini, khususnya komunikasi pendidikan (Yusuf, 2010: 50).

Berbicara tentang pembangunan pendidikan, artinya adalah bagaimana proses pengembangan SDM, Ada dua gelombang utama yang berkaitan dengan hal itu yakni; Teknologi dan Komunikasi, keduanya merupakan dua hal yang saling berjalan beriring. Yang mau tidak mau harus dihadapi oleh setiap manusia dan masyarakat.Tilaar (1990). Pendidikan harus dengan cermat mengetahui karakteristik dari gelombang tersebut agar dapat dipersiapkan upaya penanggulangan kekuatan-kekuatan yang mengikutinya atau memanfaatkannya untuk tujuan-tujuan positif. Kemajuan teknologi (komunikasi) tentunya akan mengubah bagaimana proses pendidikan itu akan berjalan, mengubah fungsi pengajar dalam proses pembelajaran, begitu juga sarana prasana pembelajaran yang tersedia berkat dukungan teknologi.

Berkaitan dengan hal di atas, salah satu isu strategis yang menjadi fokus utama dalam agenda pembangunan pendidikan adalah peningkatan mutu pendidikan melalui Indeks Prestasi Manusia (IPM) nya. Pendidikan mempunyai peranan dalam meningkatkan kualitas manusia sebagai sumber daya pembangunan dan menjadi titik sentral dalam upaya keberhasilan pencapaian tersebut. Namun demikian bukan perkara mudah untuk melaksanakan program pembangunan pendidikan tersebut. Untuk itulah, proses revitalisasi pembangunan pendidikan melalui pendekatan komunikasi pendidikan perlu dilakukan.

\section{PEMBAHASAN}

Berbicara revitalisasi, tentu bukan perkara yang mudah, sebuah revitalisasi. Menuntut persiapan dan perencanaan yang matang, begitupun dalam revitalisasi pembangunan pendidikan. Maka dituntut berbagai terobosan-terobosan yang tepat dalam pelaksanaan revitalisasi tersebut. Revitalisasi adalah suatu proses atau cara dan perbuatan untuk menghidupkan atau menggiatkan kembali berbagai program kegiatan apapun. Secara umum pengertian revitalisasi merupakan usaha-usaha 
untuk menjadikan sesuatu itu menjadi sangat penting dan perlu sekali. (Effendy dalam Marhaeni, 2016 : 60).

Beragam kata revitalisasi sering dipergunakan untuk melakukan suatu tujuan. Demikian pula dalam pembahasan ini yakni revitalisasi pembangunan pendidikan. Apa sebenarnya yang harus dilakukan dalam revitalisasi tersebut, tentu harus dipahami pula bahwa pembangunan nasional (Indonesia) adalah dalam rangka pembangunan manusia seutuhnya, yaitu bagaimana terpenuhinya kebutuhan lahir dan kepuasan bathin. Dalam hal ini tentunya aspek pendidikan menjadi objek utama dalam meningkatkan taraf kehidupan manusia sebagai wujud konkrit atas pentingnya pendidikan sesuai dengan yang diamanatkan UUD 1945 pasal 31, bahwa pemerintah bertanggung jawab atas pendidikan bagi seluruh rakyat Indonesia. Pasal 31 Ayat 1 berbunyi "Setiap warga negara berhak mendapat pendidikan", Ayat 2 berbunyi "Setiap warga negara wajib mengikuti pendidikan dasar dan pemerintah wajib membiayainya". Pembangunan pendidikan adalah proses perombakan struktural sub sistem administratif yang berkenaan dengan pengelolaan pendidikan dan subsitem operasional yang berkenaan dengan pengelolaan pendidikan dan pelaksanaan kegiatan belajar mengajar setiap satuan pendidikan agar tercapai tingkat pertisipasi, efisiensi, efektivitas, dan relevansi pendidikan yang tinggi. Pembangunan Pendidikan merupakan subordinat atau bagian dari keseluruhan Pembangunan Nasional Indonesia. Pembangunan Nasional Indonesia mencakup tujuh bidang yaitu bidang ekonomi; bidang kesejahtraan rakyat, pendidikan, dan kebudayaan; bidang keagamaan dan kepercayaan kepada Tuhan YME; bidang ilmu pengetahuan dan teknologi; bidang hukum; bidang politik, aparatur negara, penerangan, komunikasi dan media massa; bidang pertahanan dan keamanan.

Apabila Meminjam gagasan dari Cummings dan Williams (2005: 125), dimana ia mengidentifikasikan enam model pembaharuan kebijakan pendidikan yang muncul sepanjang paruh terakhir abad ke-20. Keenam model tersebut ialah model: (1) neo-colonial, (2) centralised, (3) decentralised regionalisation, (4) decentralised-sectoral, (5) community-based, dan (6) transformative. Dari keenam model tersebut penulis memilih pendekatan transformatif sebagai jalan keluar atas permasalahan pendidikan yang ada. Disini, penulis memandang perlunya 
implementasi pendidikan transformatif sesegera mungkin dengan skala nasional dan didukung oleh keterlibatan aktif seluruh elemen bangsa untuk memperbaiki mutu pendidikan di Indonesia sebagai bentuk pembangunan pendidikan yang berkelanjutan.

Pendidikan transformatif memiliki visi untuk mengubah masyarakat tradisional menjadi masyarakat modern. Pendidikan transformatif berusaha untuk mengubah karakter masyarakat indonesia yang kental dengan nilai etika dan estetika kehidupan agraris yang kurang familiar dengan perkembangan ilmu pengetahuan dan teknologi menjadi lebih modern dan peka terhadap perkembangan ilmu pengetahuan dan teknologi sesuai dengan tuntutan jaman tanpa harus kehilangan jati diri bangsa. Pendidikan transformatif berusaha menyeimbangkan antara kecerdasan intelektual dan ESQ (emotional spiritual quotient) peserta didik. Hal yang juga tidak dilupakan adalah mengenai pendidikan karakter/jati diri bangsa Indonesia. pendidikan transormatif mengedepankan pada orientasi proses belajar yang interaktif, kreatif, kritis dan partisipatif. Dengan diselenggarakannya pendidikan secara interaktif dan partisipatif maka peserta didik dilibatkan penuh dalam proses pengajaran. Mereka menjadi subjek dan bukan objek dari pembelajaran. kebutuhan peserta didik akan kenyamanan dapat terpenuhi. Sehingga motivasi belajar mereka akan meningkat. Pendidikan transformatif memfasilitasi peserta didik untuk secara mandiri dapat memberi solusi atas permasalahan yang ada. Diarahkan untuk bisa mengembangkan diri mereka sendiri. Jika sudah demikian, maka kegiatan belajar akan lebih menyenangkan, pembentukan karakter peserta didik jauh lebih optimal dan efek jangka panjangnya peserta didik menjadi insan-insan terdidik yang aktif, kreatif, inovatif dalam menyikapi perubahan dan mampu survive dengan lingkungan mereka. Guna menunjang pendidikan transformatif, diperlukan juga komunikasi yang berjalan secara efektif.

Komunikasi adalah proses penyampaian pesan-pesan dari sumber ke suatu penerima, dengan mudah dapat dilihat bagaimana faktor-faktor komunikasi terlibat secara vital dalam bentuk aspek proses keputusan yang secara keseluruhan membentuk perubahan sosial. Meski komunikasi tidak sinonim dengan perubahan sosial, namun komunikasi merupakan suatu elemen penting dalam proses perubahan sosial. Secara esensial, konsep perubahan sosial selain mencakup proses 
komunikasi, juga konsekuensi individual dan sosial sebagai hasil mengadopsi atau penolakan terhadap suatu inovasi. Dalam mengkaji perubahan sosial, perhatian kita adalah pergeseran struktur dan fungsi dari suatu sistem sosial, sekaligus proses melalui mana pergeseran tersebut terjadi. Komunikasi sering berfokus pada upaya melakukan perubahan dalam pengetahuan atau sikap dengan mengubah tatanan sumber, pesan, saluran atau penerima dalam proses komunikasi.

Berkaitan dengan apa yang dijelaskan di atas, proses revitalisasi pembangunan pendidikan secara transformatif diperlukan melalui bagaimana berbagai elemen masyarakat untuk ikut terlibat di dalam proses pembangunan pendidikan itu sendiri, karena itu diperlukan strategi pembangunan pendidikan melalui pendekatan komunikasi pendidikan yang kreatif, edukatif, dan inovatif, dan dapat mendorong partisipasi masyarakat bersama-sama dengan pemerintah untuk ikut terlibat dalam program pembangunan yang berkelanjutan di antaranya dengan membangun information literacy dan media literacy, strategi computer mediated communication (CMC), peningkatan kompetensi pengajar, optimalisasi media dan teknologi komunikasi instruksional, serta optimalisasi sistem instruksional melalui kurikulum.

\section{Information Literacy dan Media Literacy}

Mempelajari Information Literacy dan Media Literacy melalui Komunikasi Pendidikan; Secara umum, istilah literasi adalah kemampuan membaca dan menulis huruf latin jika di Indonesia). Kebalikannya adalah illiterate yang di-Indonesiakan menjadi buka huruf atau buka aksara. Secara khusus istilah literasi bisa didefinisikan sebagai kemampuan teknis dalam men-decode atau mereproduksi lambang-lambang tulisan, hasil cetakan, atau tulisan dalam kalimat dan kata-kata dalam bentuk lambang. Dalam perkembangan selanjutnya literasi dikaitkan dengan kemampuan berkomunikasi secara tertulis, bukan dengan komunikasi lisan. Sekarang konsep literasi juga sudah digunakan secara lebih bervariasi dalam konteks kemampuan memahami perkembangan teknologi seperti komputer, digital, grafik, matematik, dan belakangan informasi. Literasi bukan sebuah karakteristik manusia sejak lahir, namun lebih merupakan sebagai kemampuan yang bisa

dipelajari, baik di lingkungan sekolah maupun di luar sekolah. Bahkan dalam 
perkembangan terakhir, ada kecenderungan literasi digunakan sebagai kemampuan dalam berinteraksi seseorang dan masyarakat dengan lingkungannya (Yusuf, 2010: 74). Literasi terus berkembang. Kita tidak bisa lagi hanya menyebut literasi hanya berkaitan dengan membaca dan menulis huruf dan angka. Karena huruf dan angka itu pada dasarnya merupakan sarana pembawa, penyampai dan penyimpan informasi. Kini, informasi tersebut kita peroleh bukan hanya melalui huruf dan angka. Boleh jadi, saat membaca, kita hanya memerlukan kemampuan membaca huruf dan angka. Namun, untuk informasi yang disajikan melalui siaran televisi, kita tidak hanya memerlukan kemampuan membaca huruf dan angka melainkan juga "membaca" televisi, yang biasa disebut melek-media (Iriantara, 2009: 9). Konsep baru literasi memasukkan komponen-komponen berikut ini untuk memperkaya pengetahuan dan keterampilan berpikir kritis manusia dengan memadukan perkembangan sosial, profesional dan teknologi, yaitu:

1. Literasi teknologi: kemampuan untuk memanfaatkan media baru seperti internet untuk mengakses dan mengkomunikasikan informasi secara efektif.

2. Literasi informasi: kemampuan untuk mengumpulkan, mengorganisasikan, menyaring dan mengevaluasi informasi dan untuk membentuk opini yang kokoh berdasarkan kemampuan tersebut.

3. Kreativitas media: kapasitas individu yang terus berkembang di mana pun untuk membuat dan menyebarluaskan konten pada berbagai khalayak.

4. Tanggung jawab dan kompetensi sosial: kompetensi untuk memperhitungkan akibat-akibat sosial dari publikasi on-line dan tanggung jawab terhadap anak-anak (Bertelsman \& AOL Time-Warner dalam Iriantara, 2009: 10).

Pemahaman akan literasi media ini amat penting dalam menunjang keberhasilan pendidikan. Kirwan et.al (dalam Iriantara, 2009: 20) menyebutkan beberapa alasan mengenai pentingnya pendidikan media/literasi media ini. Alasan yang dikemukakan Kirwan et.al ini pada umumnya menjadi alasan juga bagi pengembangan pendidikan media/literasi media di negara-negara lain. Alasan menyelenggarakan pendidikan media/literasi media adalah:

1. Kita perlu mendapatkan cukup informasi (well-informed) tentang media, serta mengapa dan bagaimana informasi dikomunikasikan. Manusia perlu memiliki kemampuan untuk menilai informasi yang bisa dipercaya (reliable). 
2. Media massa merupakan bagian penting bagi pengalaman banyak orang sehingga kita perlu mengkaji media massa selain bentuk-bentuk informasi dan hiburan lainnya seperti buku.

3. Dipandang penting untuk memberikan pembelajaran atas pengalaman anak-anak mengkonsumsi media.

4. Media massa merupakan sumber pokok informasi, menjadi bagian kultur kita, dan pembelajar hendaknya memahami bagaimana media massa membentuk makna.

Pada sisi lain, pendidikan media merupakan bentuk pemberdayaan khalayak media. Hal ini sesungguhnya terkait dengan tujuan pendidikan media yang tidak lagi bertujuan melindungi khalayak media sebagai konsumen produk yang dihasilkan industri media, tetapi juga mempersiapkan khalayak sebagai konsumen media untuk hidup di dunia sosialnya yang sangat bergantung pada media massa. Karena itu, salah satu prinsip dalam pendidikan media atau literasi media adalah memberdayakan khalayak. Disebut memberdayakan, karena dalam pandangan Bow (dalam Iriantara, 2009: 20). "Literasi media menjadi kompas baru dalam mengarungi dunia media." Karena, dalam penilaian Bow, "Bila orang tidak diberdayakan, maka orang akan menjadi korban media.” Di Indonesia, pendidikan media untuk mempersiapkan generasi muda menghadapi kehidupan di dunia sesakmedia ini, relatif baru. Sebagai sesuatu yang relatif baru, tentu kita masih belum bisa berharap banyak ada keseragaman aspek-aspek yang harus dipelajari. Apalagi bila kita menginginkan ada semacam standarisasi untuk pendidikan media ini. Namun, apa pun yang sudah dilakukan, dengan keragamannya, sudah merupakan langkah penting untuk pengembangan literasi media di Indonesia. Kita sudah memulai pendidikan media ini, sehingga yang perlu kita lakukan berikutnya adalah menemukan metode pembelajaran yang paling efektif dan cocok untuk situasi masyarakat kita. Kalaupun ada keragaman, kita bisa memandangnya sebagai bagian dari proses yang harus kita lalui untuk menuju masyarakat melek media di Indonesia (Iriantara, 2009: 96).

Dengan mempertimbangkan karakteristik pembelajar orang dewasa, pendekatan andragogi dan paedagogi dalam satu kontinum yang bersifat paralel, 
serta pengetahuan tentang media yang dimiliki warga belajar dalam proes pembelajaran literasi media untuk orang dewasa, digunakan pendekatan partisipatif. Pendekatan pembelajaran seperti ini dikemukanan oleh Stole (2001), Ruyle (1995: 310) dan Kindervatter (1979: 247). Dalam pendekatan proses pembelajaran ini, inisiatif pembelajaran akan lebih banyak diarahkan oleh warga belajar sendiri. Meski demikian, fasilitator masih berperan untuk menjelaskan aspek-aspek yang terkait dengan pengetahuan tentang literasi media. Dengan demikian, pendekatan pembelajaran partisipatif dan proses pembelajaran yang sejalan dengan karakteristik pembelajar dapat dipergunakan dalam pelatihan literasi media ini.

Model pelatihan melek media untuk pemberdayaan khalayak media massa ini disusun dengan memadukan tahapan pelatihan yang dikembangkan Nadler (1982: 12) dan Goad (1982: 11) yang dipadukan dengan konsep pendidikan nonformal sebagai proses pemberdayaan. Kindervatter (1979), serta Model Mancraft dari Stole (2001). Model pelatihan melek media ini pun mendasarkan diri pada teori yang dikembangkan dalam ilmu komunikasi yang melihat media massa bukan hanya merefleksikan realitas melainkan juga merepresentasikan realitas.

Dengan memandang media massa bukan merefleksikan, melainkan merepresentasikan realitas itu, maka apa yang disajikan media massa pada dasarnya merupakan hasil olahan atas realitas yang menggunakan cara den pendekatan tertentu yang membuat isi media massa menjadi menarik (Fiske dan Sudibyo dalam Iriantara, 2009: 108). Sejalan dengan hal tersebut, dalam dunia media massa mutakhir sendiri ada dua hal penting menurut Sudibyo (dalam Iriantara, 2009: 108) memengaruhi media massa dan pesan yang disampaikannya yaitu pekembangan teknologi. Pemberdayaan khalayak yang dilakukan di berbagai negara untuk meningkatkan kemampuan khalayak media tersebut dikenal dengan istilah literasi media. Pada dasarnya, literasi media merupakan upaya untuk meningkatkan keberdayaan khalayak sebagai konsumen media. Dengan lahirnya khalayak yang memiliki kemampuan melek media, mekanisme kontrol atas isi tayangan media massa akan menjadi lebih besar, karena khalayak mengetahui apa yang sepatutnya dilakukan media massa. Khalayak juga mengetahui apa yang boleh dan tidak boleh disajikan media massa, termasuk media televisi. 
Dalam proses pembelajaran tersebut, metode pembelajaran yang dipergunakan adalah kontinum andragogi-paedagogi. Hal ini sejalan dengan pandangan bahwa antara paedagogi dan andragogi bukanlah dua metode pembelajaran yang saling bertentangan melainkan berada dalam satu kontinum. Dengan demikian, kedua metode pembelajaran tersebut dipergunakan sejalan dengan perkembangan kebutuhan pelaksanaan pelatihan (Iriantara, 2010: 111).

\section{CMC (Computer Mediated Communication)}

Strategi CMC (Computer Mediated Communication); Ada beberapa langkah strategis yang bisa dilakukan seorang komunikator instruksional dalam melakukan tugasnya di lapangan, yakni strategi dalam menggunakan berbagai media dan peralatan yang secara khusus dirancang untuk memperlancar pencapaian tujuan instruksional. Namun karena yang dimaksudkannya adalah khusus dalam strategi instruksional dalam CMC (computer mediated communication), maka yang paling umum bisa dilakukan adalah dengan menggunakan media CMC dimaksud yang antara lain e-mail, instant messaging, newsgroup, web-based chat, distance learning, dan e-learning.

1. E-mail: bisa digunakan oleh guru, dosen, dan para praktisi komunikasi insruksional di lapangan dalam melakukan kegiatan instruksionalnya kepada pihak sasaran. Materi pelajaran bisa didiskusikan dan disampaikan melalui e-mail, dan pihak sasaran pun bisa memberikan jawaban atau tanggapan atau menyelesaikan tugas-tugas instruksionalnya lewat e-mail.

2. instant messaging: dikenal juga dengan sebutan internet text messaging, yaitu suatu ruang dalam internet yang gunanya untuk menyampaikan pesan singkat dan langsung kepada orang lain. Fasilitas ini bisa digunakan baik oleh guru, dosen atau komunikator instruksional di lapangan dengan sasaran didiknya. Mereka bisa berkomunikasi secara langsung jika diperlukan. Proses komunikasi dengan teknik ini bisa dilakukan setiap saat tanpa harus bertemu secara tatap muka.

3. newsgroup: dikenal juga degan konsep internet discussion group, yaitu suatu kelompok diskusi yang menggunakan sistem jaringan komputer (internet), di mana setiap anggota menuliskan pesan atau gagasangagasannya untuk kemudian ditanggapi oleh anggota yang lain yang meminati topik bahasan yang sama. Dalam pelaksanaannya, para anggota dimaksud bisa antara komunikator instruksional dan para siswa dan sasaran didiknya.

4. web-based chat: dikenal juga dengan istilah chat, chat room, yakni suatu program atau ruangan dalam komputer internet yang berfungsi untuk saling berkomunikasi tekstual secara langsung dengan orang lain dalam 
jaringan internet. Pelakunya bisa dua orang atau lebih. Umumnya chatting hanya diperuntukkan bagi komunikasi secara informal melalui internet, namun sekarang berkembang menjadi beragam fungsi komunikasi, termasuk bisa juga digunakan oleh komunikator instruksional dengan komunikannya sebagai contoh antara guru dan siswanya. Tentu saja topik pembicaraannya adalah masalah-masalah hubungan proses belajar dan mengajar antara kedua belah pihak.

5. distance learning: yakni berkomunikasi secara maya dengan orang lain yang secara geografis jauh jaraknya. Hubungan ini dibatasi hanya dalam konteks proses belajar dan mengajar, proses instruksional. Para siswa dan mahasiswa bisa membaca dan mengakses sumber-sumber informasi pendidikan dari guru maupun dosennya, dan bahkan bisa berkomunikasi secara tekstual dan langsung dalam pelaksanaan proses instruksionalnya. Ketika Anda sebagai dosen atau guru tidak sempat hadir dalam kelas karena kesibukan dan tugas penting yang tidak bisa diwakilkan misalnya, maka proses belajar mengajar dengan mahasiswa bisa tetap berlangsung dengan menggunakan konsep belajar jarak jauh ini.

6. e-learning: suatu sistem atau konsep pendidikan yang memanfaatkan teknologi informasi dalam proses belajar mengajar. Karakteristik $E$ learning bersifat jaringan, yang membuatnya mampu memperbaiki secara cepat, menyimpan atau memunculkan kembali, mendistribusikan, dan sharing pembelajaran dan informasi (Yusuf, 2010: 231).

Penggabungan teknologi komputer dengan teknologi komunikasi melahirkan suatu fenomena yang mengubah konfigurasi model komunikasi kon vensional, dengan melahirkan kenyataan dalam dimensi ketiga yang dikenal dengan kenyataan maya (Virtual Reality) yang melahirkan suatu format masyarakat lainnya. masyarakat yang dibentuk dalam kenyataan virtual di kenal sebagai masyarakat cyber society. tempat yang memungkinkan adanya hubungan antar manusia.

Perspektif CMC merupakan kelanjutan dari model-model saluran komunikasi yang pertama kali dibahas pada 1950-an. Jadi, sebelum melihat fiturfitur kontemporer CMC, ada baiknya mensketsa kontur utama teori informasi. Anehnya, teori-teori ini kurang relevan untuk broadcast daripada untuk dyadic reciprocity (timbal-balik dua pihak)-baik itu yang tatap-muka langsung maupun yang dihubungkan lewat elektronik. Fakta bahwa mereka mencapai pengaruh cukup besar di Amerika Serikat dalam era puncak broadcast adalah menentang fakta bahwa mereka tidak pernah mampu mengakomodasi fenomena tentang 
performativitas, tentang tontonan, dan reification. Model-model komunikasi dyadic tidak sangat membantu dalam menjelaskan apa yang terjadi ketika sejumlah kecil pusat produksi budaya mengirim pesan ke massa yang jumlahnya tak tentu (Holmes, 2012: 117).

Sekilas computer mediated communication dan perannya dalam pendidikan jarak jauh. Penggunaan komputer sebagai sarana untuk berkomunikasi dikenal dengan Computer Mediated Communication (CMC). Dalam aplikasi CMC dapat berbentuk e-mail, bulletin board atau computer conferencing. CMC telah di gunakan secara luas dalam berbagai organisasi ataupun dunia pendidikan, jarak jauh CMC mempunyai peran yang sangat penting dalm meningkatkan mutu dan effektifitas belajar jarak jauh. Salah satu keunggulan dari CMC di bandingkan dengan media komunikasi lain (misal audiographcis atau video conference) adalah kemampuannya dalam menyediakan komunikasi asynchronous (tak serempak). Dalam komunikasi semacam ini para peserta dari conference tak harus hadir pada waktu yang sama. Jelas keunggulan ini sangat bermanfaat dalam pendidikan jarak jauh yang menekankan fleksibilitas dan keluasaan para pesertanya untuk hadir dalam proses pembelajaran. Selain itu CMC digunakan untuk membawakan metode belajar yang lebih menekankan pada diskusi dan pertukaran ide (pendekatan cognitive-constructivist) dan tidak semata-mata menggunakan pendekatan behavioristic (Pramono, 2017).

Adapun dampak positif dalam penerapan konsep Computer Mediated Communication (CMC) dalam dunia pendidikan adalah sebagai berikut :

1. Informasi yang dibutuhkan akan makin cepat dan mudah di akses untuk kepentingan pendidikan

2. Inovasi dalam pembelajaran makin berkembang dengan adanya inovasi elearning yang makin memudahkan proses pendidikan

3. Kemajuan Teknologi dan Informasi juga akan memungkinkan berkembangnya kelas Virtual atau kelas yang berbasis Teleconference yang tidak mengaharuskan sang pendidik dan peserta didik berada dalam satu ruangan

4. Sistem administrasi pada sebuah lembaga pendidikan akan makin mudah dan lancar karena penerapan sistem teknologi informasi komunikasi (Ancok, 2000). 


\section{Kompetensi Pengajar}

Meningkatkan Kompetensi Pengajar sebagai Komunikator Komunikasi Pendidikan; Berdasarkan Undang-Undang Nomor 14 Tahun 2005 tentang Guru dan Dosen, pada pasal 10 ayat (1) menyatakan bahwa

"Kompetensi guru sebagaimana dimaksud dalam Pasal 8 meliputi kompetensi pedagogik, kompetensi kepribadian, kompetensi sosial, dan kompetensi profesional yang diperoleh melalui pendidikan profesi”.

Agar keberadaan Sumber Daya Manusia (SDM) memiliki kontribusi atau peran yang maksimal dalam pencapaian misi dan tujuan pendidikan, perlu dilakukan upaya peningkatan kualitas secara komprehensif dan terus menerus. Salah satu upaya meningkatkan kualitas sumber daya manusia itu adalah melalui pelatihan dan pengembangan.

Pelatihan dan pengembangan memiliki kontribusi besar dalam peningkatan kompetensi individu. Pelatihan dan pengembangan dapat menjadi media atau wahana untuk melakukan transfer atau internalisasi nilai-nilai strategis organisasi, membangun budaya organisasi, kompetensi inti organisasi kepada anggota atau individu. Dalam konteks fungsi pertama, pelatihan dan pengembangan mrupakan upaya menyelaraskan antara kompetensi individu dengan strategi organisasi ataupun kompetensi organisasi. Kedua, pelatihan dan pengembangan dapat berfungsi sebagai perbaikan kinerja individu dalam organisasi. Pelatihan dan pengembangan dalam konteks ini merupakan wahana atau media untuk melakukan injeksi semangat atau mendongkrak kinerja sejalan dengan standar kinerja yang telah ditetapkan. Pelatihan dilakukan sebagai solusi terhadap problema kinerja guru dan kinerja sekolah.

Dalam perspektif praktik manajemen SDM, sering kali dijumpai upaya peningkatan kualitas SDM dilakukan dengan berbagai penyebutan, yaitu: pendidikan (education), pelatihan (training), dan pengembangan (development). Bahkan, akhir-akhir ini muncul istilah pemberdayaan (empowerement). Keempat terminologi tersebut sering kali diartikan sebagai upaya meningkatkan kualitas guru/pengajar.

Pengembangan sumber daya manusia sebagai bagian integral dari manajemen SDM memiliki peran yang strategis dalam kerangka pencapaian tujuan 
organisasi. Dalam arti luas, pengembangan sumber daya manusia secara substansi dipahami sebagai proses peningkatan potensi atau kemampuan, kompetensi, dan karier dari guru/pengajar yang bersangkutan. Dimensi pengembangan, di samping peningkatan potensi rasio (pemikiran, logika, IQ, rasa (emosi atau EQ, kompetensi), juga mencakup peningkatan etik dan moralitas atau spiritual quotience (SQ) (Sudarmanto, 2015: 226-227).

\section{Media Komunikasi dan Teknologi Instruksional}

Sekarang ini, dengan kehadiran komputer untuk aplikasi pendidikan dan instruksional, terasa sangat dimudahkan pelaksanaannya. Para guru, dosen, dan praktisi komunikasi di lapangan bisa menampilkan pesan-pesan pendidikan dan instruksionalnya melalui beragam teknik presentasinya dengan bantuan komputer multimedia. Pengertian multimedia itu sendiri cukup beragam seperti yang tercantum dalam kamus Encarta tahun 2007, sebagai berikut:

1. Film suara yang ada dalam komputer, yang meliputi program-program, software dan hardware yang bisa digunakan secara luas dalam berbagai media seperti film, video, musik, teks, grafik, dan angka.

2. Penggunaan berbagai bahan dalam seni, terutama seni plastik dan lukis.

3. Penggunaan semua jenis media komunikasi, khususnya dalam marketing, seperti radio, televisi dan pers, disebut media promosi atau media marketing.

4. Penggunaan media dalam pengajaran, misalnya media film, video, gambar, lukisan, dan musik, sebagai tambahan atau kelengkapan terhadap metode pengajaran dan pembelajaran secara konvensional.

Dalam dunia pendidikan dan instruksional, alat peraga pendidikan atau yang sekarang kita sebut dengan media instruksional, sangatlah diperlukan kehadirannya. Sebab media dimaksud mampu menambah kejelasan pesan-pesan instruksional yang disampaikan guru, dosen, ataupun praktisi komunikasi di lapangan. Multimedia instruksional bisa memanfaatkannya untuk tujuan mempermudah pencapaian tujuan-tujuan instruksional yang ditetapkan para instruktur dan praktisi komunikasi pendidikan pada umumnya (Yusuf, 2010: 234). 
Adapun tentang teknologi instruksional, dalam pengertiannya yang sempit orang sering menghubungkan teknologi instruksional dengan media, bahkan teknologi instruksional dianggap sebagai media. Media artinya perantara, saluran pembawa pesan. Dengan demikian, dalam konteks ini teknologi instruksional dianggap sebagai teknologi pembawa pesan, pesan-pesan instruksional tentunya. Pengertian ini muncul dari hasil revolusi komunikasi yang bisa dimanfaatkan untuk kepentingan pendidikan, khususnya kegiatan belajar dan mengajar selain bahanbahan yang sudah ada seperti guru, papan tulis, dan alat-alat pengajaran tradisional lainnya. Media yang dimaksudkan di sini adalah radio, televisi, film, video kaset, transparansi, komputer dan lain-lain, yang dirancang khusus untuk aplikasi kegiatan (software) dan perangkat kerasnya (hardware) yang merupakan satu kesatuan yang tidak bisa dipisahkan karena masing-masing tidak bisa berdiri sendiri. Contohnya, film tanpa proyektor tidak ada gunanya. Ada media pendidikan, ada pula media instruksional. Yang pertama lebih luas pengertiannya daripada yang terkahir karena pengertian yang terakhir ini konsepnya khusus untuk kepentingan instruksional, pembelajaran, yang hanya merupakan bagian saja dari konsep pendidikan secara utuh (Yusuf, 2010: 239).

\section{Sistem Instruksional}

Pemanfaatan Komponen Sistem Instruksional Melalui Kurikulum; Komponen-komponen sistem instruksional yang terdiri dari pesan, orang, bahan, alat, teknik, dan lingkungan itu dikatakan juga sebagai sumber-sumber belajar karena pada dasarnya kegiatan belajar seseorang pada umumnya diperoleh dari interaksinya dengan sumber-sumber tadi, baik seluruhnya atau sebagiannya. Orang bisa belajar dari pesan-pesan instruksional yang ditulis orang pada berbagai bahan, contohnya buku, majalah, surat kabar, dan sumber bacaan lainnya yang bisa berfungsi sebagai bahan yang berkedudukan sebagai sumber-sumber belajar. Demikian pula orang bisa melakukan kegiatan belajar tanpa bahan-bahan tersebut, tetapi cukup dengan orang saja, misalnya belajar melalui kuliah atau ceramah oral serta mendengarkan komunikasi lisan lainnya. Hal ini berlaku juga untuk komponen sumber-sumber belajar lainnya, semuanya berfungsi menunjang kelancaran proses belajar sasaran. 
Karena kegiatan instruksional dipandang sebagai suatu sistem, maka tentu komponen-komponen yang terlibat di dalamnya tidak dianjurkan untuk berfungsi secara terpisah-pisah, tetapi harus merupakan satu kesatuan yang berintegrasi. Bagaimanapun, hasil belajar yang hanya berasal dari satu sumber tidak akan efektif dibandingkan dengan apabila belajar tersbut merupakan hasil interaksi dari berbagai sumber. Karena itu, faktor pemanfaatan sumber-sumber belajar menjadi penting.

Sumber-sumber belajar, apabila dilacak lebih jauh, bisa dicirikan dari sumber-sumber belajar yang dirancang khusus untuk tujuan-tujuan belajar, dan sumber-sumber belajar yang langsung tersedia apa adanya di alam. Sumber-sumber belajar jenis yang terkahir ini tinggal memanfaatkan saja tanpa perlu mengolahnya lebih dahulu. Buku, majalah, surat kabar, dan media cetak lainnya, adalah sumbersumber belajar yang dirancang pengadaannya, juga berbagai pesan yang direkam ke dalam perekaman yang berupa perangkat lunak seperti transparansi, slide, film, atau kaset video, komputer, internet, dan lain-lain, merupakan sumber-sumber belajar yang direncanakan. Akan tetapi, lain halnya dengan data dan fakta alam secara apa adanya seperti hutan lindung, pepohonan, hewan, dan objek-objek alamiah lainnya yang merupakan sumber-sumber belajar yang sudah tersedia secara langsung tanpa dipola lebih dahulu oleh manusia. Sumber-sumber belajar jenis yang terakhir ini termasuk ke dalam kelompok komponen sistem instruksional yang tinggal dimanfaatkan. Segala jenis sumber belajar tersebut baik yang dirancang maupun yang tinggal dimanfaatkan, semuanya perlu dimanfaatkan atau didayagunakan secara optimal untuk kepentingan belajar. Tanpa pemanfaatan secara optimal sumber-sumber belajar tersebut, hasil belajar pun tentu tidak akan efektif (Yusuf, 2010: 247).

Sistem instruksional pendidikan tentu bersumber dari kurikulum pembelajaran yang diterapkan. Sehingga tidak berlebihan rasanya apabila dikatakan bahwa sistem pembelajaran atau instruksional merupakan penerapan dari kurikulum yang telah disusun sedemikian rupa. Dalam suatu pembelajaran tentunya kurikulum menjadi suatu hal yang sangat penting dalam proses belajar mengajar itu sendiri. Lazimnya kurikulum dipandang sebagai suatu rencana yang disusun untuk melancarkan proses belajar-mengajar di bawah bimbingan dan tanggung jawab 
sekolah atau lembaga pendidikan beserta staf pengajarnya. Kurikulum yang baik diharapkan dapat meningkatkan kompetensi dan kapabilitas (capability) peserta didik. Kapabilitas dalam pendidikan tinggi menyangkut keterampilan dan keilmuan profesi yang amat dibutuhkan oleh penggunanya (users) untuk menghadapi dunia kerja. Sehingga, dengan demikian pendidikan yang bermutu dapat dicapai dan dikembangkan dari waktu ke waktu. Kurikulum sebagai sumber pembelajaran harus disusun secara responsif terhadap perubahan dan tuntutan zaman. Hal ini dilakukan karena kebutuhan masyarakat terus bertumbuh seiring berkembangnya peradaban baru di era globalisasi seperti sekarang ini.

Oleh karena itu, dalam menyusun kurikulum pembelajaran guna menunjang metode model pembelajaran transformatif yang telah penulis singgung di atas. Seorang pengajar yang menjadi bagian dari adanya sistem instruksional harus mampu menerapkan beberapa strategi seperti direkomendasikan oleh Cranton \& King (dalam Sugiana, 2016: 7) sebagai berikut: (1) Menunjukkan sejumlah peristiwa yang sama sekali berbeda dari apa yang selama ini diyakini, dialami, didengar, atau dibaca seseorang yang bersangkutan; (2) Mengungkap makna yang sesungguhnya dari anggapan-anggapan yang selama ini diikuti orang secara begitu saja atau yang umumnya tak disadari orang; (3) Melakukan perenungan secara kritis dalam arti mempertanyakan atau menguji kebenaran asumsi-asumsi yang berkenaan dengan dari mana asal asumsi itu, apa sebetulnya akibat yang bakal terjadi jika mengikutinya, dan mengapa asumsi itu dipandang begitu penting; (4) Bersikap terbuka atau membuka diri terhadap pandangan orang lain yang berbeda; (5) Melibatkan seseorang pada pembicaraan-pembicaraan yang berbukti, alasanalasan yang teruji, pandangan-pandangan alternatif yang tertelusuri, dan pengetahuan-pengetahuan yang disepakati; (6) Melakukan perubahan dengan sengaja terhadap asumsi-asumsi atau pandangan-pandangan yang telah dimiliki seseorang atau masyarakat sehingga sikap mereka menjadi lebih terbuka dan lebih bijak; (7) Betul-betul melakukan tindakan perbaikan, atau bertindak, berbicara, dan berpikir yang betul-betul sejalan dengan asumsi-asumsi atau pandangan-pandangan yang telah ditransformasi.

Kelima strategi komunikasi pendidikan di atas dapat dijelaskan melalui bagan alur revitalisasi pembangunan pendidikan yang terdiri atas proses 
pembelajaran, sarana dan prasarana, serta kurikulum melalui komunikasi pendidikan berkelanjutan sebagai berikut ini:

Gambar Bagan Alur Revitalisasi Pembangunan Pendidikan

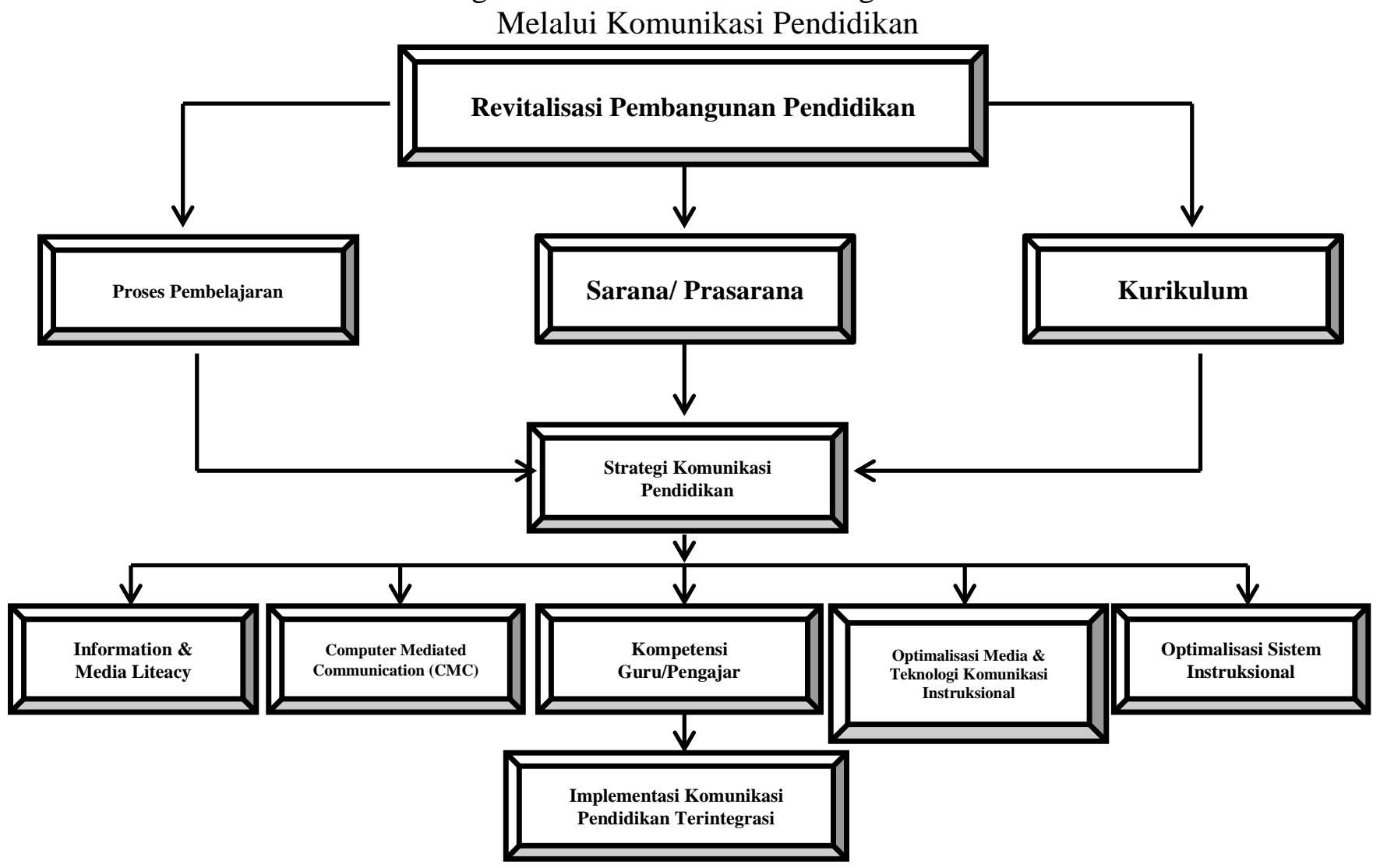

Berdasarkan apa yang telah digambarkan dalam bagan alur revitalisasi pembangunan pendidikan, menunjukkan bahwa proses revitalisasi yang terdiri dari pross pembelajaran, sarana dan prasarana, serta kurikulum dapat berjalan melalui sebuah strategi komunikasi pendidikan, yang terdiri atas peningkatan informasi literasi dan media literasi dalam dunia pendidikan, strategi computer mediated communication (CMC), kompetensi guru/pengajar, optimalisasi media dan teknologi pendidikan, serta optimalisasi sistem instruksional melalui kurikulum sehingga proses implementasi komunikasi pendidikan dalam menunjang program pembangunan pendidikan dapat berjalan sebagaimana mestinya. Aspek teknologi komunikasi dalam strategi komunikasi pendidikan mendapat banyak sorotan penulis dikarenakan teknologi komunikasi sejak perkembangannya banyak berdampak terhadap perubahan dalam masyarakat, baik yang berdampak 
perubahan ke arah yang lebih manusiawi maupun yang berdampak perubahan ke arah yang anarkis. Ada beberapa dampak sosial yang dihasilkan dari pengembangan teknologi komunikasi. Menurut Rogers (dalam Dilla, 2007: 168) ada tiga dampak akibat pengembangan teknologi komunikasi. (1) Desirable and undesirable impacts. The term desirable and undesirable is roughly equivalent to positive and negative in this context. (2) Direct and indirect impacts. (3) Anticipated and Unanticipated impact.

Secara teoretis menurut Parker dan Dunn (1972), teknologi komunikasi dan informasi mempunyai dampak positif yang dapat digunakan untuk keuntungan orang banyak dalam masyarakat, "Potensi tunggal paling besar dari penggunaan informasi adalah kesempatan untuk mengurangi biaya unit pendidikan sampai titik di mana masyarakat dapat memberikan akses yang sama dan terbuka bagi kesempatan belajar untuk semua anggota masyarakat sepanjang hidup mereka". Lebih lanjut, Parker dan Dunn (1972) mengatakan ada sejumlah kesenjangan (pengetahuan, keterampilan dan informasi) turut menyertai dampak positif dari keuntungan perkembangan teknologi komunikasi. Pelebaran kesenjangan informasi ini biasanya menyebabkan ketegangan sosial yang meningkat (Dilla, 2007: 169). Pada umumnya, saluran media massa lebih banyak digunakan untuk komunikasi informatif. Dengan saluran ini, komunikator pembangunan berusaha untuk memperkenalkan dan memberikan pengetahuan mengenai pesan-pesan pembangunan. Selanjutnya untuk perubahan perilaku, aktivitas komunikasi harus dilipatgandakan dengan menggunakan berbagai macam saluran. Lazarsfeld (dalam Dilla, 2007: 174) mengatakan bahwa media massa hanya merupakan: 1) pelipat ganda pesan dan penyebar ide secara mendatar; dan 2) penguat. Artinya, hanya didengar apabila sependapat dengan komunikan. Jadi, saluran interpersonal dipergunakan apabila kita mengharapkan efek perubahan tingkah laku (behaviour change) dari komunikan. Adapun skema hubungan antara kelima aspek komunikasi pendidikan yang saling mempengaruhi dalam menunjang pembangunan pendidikan berkelanjutan satu sama lain dapat dilihat di dalam gambar berikut: 
Gambar Skema Hubungan Strategi Komunikasi Pendidikan dalam Menunjang Pembangunan Pendidikan Berkelanjutan

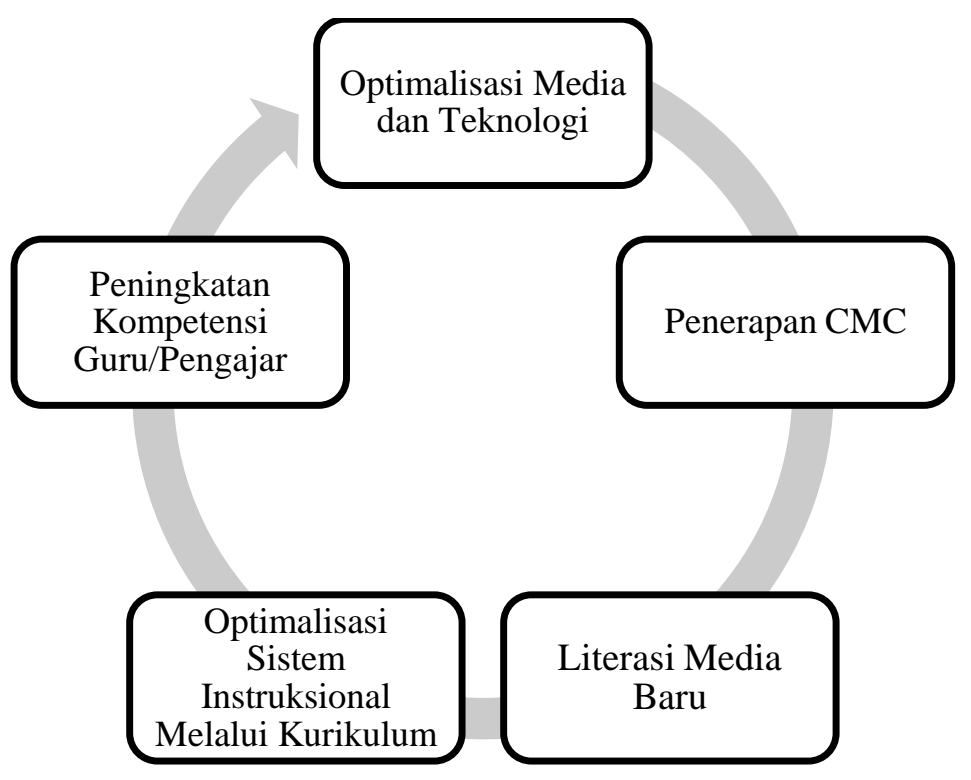

Komunikasi pendidikan mulai dari peningkatan informasi literasi dan media literasi dalam dunia pendidikan, strategi computer mediated communication (CMC), peningkatan kompetensi guru/pengajar, optimalisasi media dan teknologi instruksional, serta optimalisasi sistem instruksional melalui kurikulum ini merupakan satu kesatuan yang dapat saling mempengaruhi satu sama lain. Peranan optimalisasi media dan teknologi instruksional merupakan salah satu cara untuk mengembangkan strategi penerapan computer mediated communication (CMC) yang pada akhirnya menjadi suatu literasi media baru dalam dunia pendidikan, ketiga hal ini juga memiliki dampak yang signifikan terhadap optimalisasi sistem instruksional melalui kurikulum dari berbagai sumber pembelajaran dalam menunjang proses belajar mengajar. Sehingga, untuk menyelaraskan perkembangan teknologi ini dengan satuan kurikulum yang berlaku, kompetensi guru/pengajar pun perlu mendapatkan perhatian secara khusus melalui pengembangan dan pelatihan yang diberikan guna meningkatkan kompetensi dan kinerja mereka sesuai dengan tujuan instruksional pendidikan yang tercantum dalam sistem pembelajaran yang telah didesain sedemikian rupa guna mewujudkan pembangunan pendidikan berkelanjutan. 
Dengan adanya kelima faktor komunikasi pendidikan yang saling berkesinambungan ini maka proses pembelajaran transformatif yang terjadi dalam beberapa fase, yakni: (1) pembentukan frame of reference (kerangka ajuan) oleh masing-masing individu, (2) pengenalan terhadap kerangka acuan individu lain (3) dialog mengenai berbagai kerangka acuan yang berbeda, dan (4) proses refleksi dan tinjauan ulang dari kerangka acuan semula yang terdiri atas 4 unsur utama, yakni pemahaman terhadap konteks, action-oriented teamwork, knowledge network dan reflexive discourse akan dapat berjalan lebih efektif apabila kelima faktor komunikasi pendidikan tersebut dapat diimplementasikan secara integratif dan berkelanjutan (continous). Sementara itu, Transformative learning merupakan salah satu bentuk dari communicative learning. Communicative learning adalah proses learning yang menekankan pada penciptaan komunikasi dan pemahaman mengenai meaning atau pemahaman yang dimiliki oleh orang lain. Dialog merupakan aktivitas penting dalam communicative learning yang memungkinkan terciptanya transfer informasi dan pengetahuan dari satu obyek ke obyek lainnya. (Nasution, 2017).

\section{PENUTUP}

Bertitik tolak dari uraian pembahasan tersebut di atas dapat disimpulkan bahwa hasil kajian menunjukkan bahwa revitalisasi pembangunan pendidikan melalui pendekatan komunikasi pendidikan amat sangat penting dilakukan untuk membuat strategi maupun program-program komunikasi pendidikan yang dapat menggerakkan partisipasi masyarakat dalam pembangunan pendidikan, karena pendidikan pada hakekatnya merupakan bentuk hubungan yang paling esensial dalam kehidupan manusia. Pendidikan akan berjalan baik apabila strategi komunikasi pendidikan dapat diimplementasikan demi terlaksananya pembangunan pendidikan yang berkelanjutan. Pendidikan merupakan hal penting dalam kehidupan manusia. Sebagaimana dinyatakan dalam Undang-Undang Dasar Negara Republik Indonesia Tahun 1945 mengamanatkan Pemerintah mengusahakan dan menyelenggarakan satu sistem pendidikan nasional yang meningkatkan keimanan dan ketakwaan kepada Tuhan Yang Maha Esa serta akhlak mulia dalam rangka mencerdaskan kehidupan bangsa. Dan upaya pemerintah 
membentuk satu sistem pendidikan nasional yang bernafaskan nilai-nilai Undangundang telah di manifestasikan ke dalam implementasi Undang-Undang No. 20 Tahun 2003 tentang Sistem Pendidikan Nasional. Di dalamnya, ada kewajiban untuk menyelenggarakan suasana belajar dan proses pembelajaran dimana peserta didik terlibat secara aktif mengembangkan potensi dirinya untuk memiliki kekuatan spiritual keagamaan, pengendalian diri, kepribadiaan, kecerdasan, akhlak mulia, serta keterampilan yang diperlukan dirinya, masyarakat, bangsa, dan Negara. Oleh karena itu, seharusnya pendidikan di Indonesia diarahkan kepada pembentukan manusia yang utuh guna menciptakan pribadi yang unggul secara intelektual (IQ), emosional (EQ) dan Spiritual (SQ).. Melalui implementasi komunikasi pendidikan, keberhasilan pencapai program pendidikan diharapkan dapat terwujud. Pendidikan merupakan salah satu penentu kemajuan suatu bangsa dan pembentuk para National Builders yang akan berkompetisi secara global, hal ini dikarenakan pendidikan mempunyai peranan dalam meningkatkan kualitas manusia sebagai sumber daya pembangunan dan menjadi titik sentral dalam upaya keberhasilan pembangunan itu sendiri.

\section{DAFTAR RUJUKAN}

Ancok, Djamaludin. 2000. "Dampak Teknologi Internet Pada kehidupan Manusia dan Pengelolaan Institusi Pendidikan", makalah pada peringatan Lustrum ke tujuh Fakultas Psikologi Universitas Gadjah Mada Yogyakarta. 15 Januari 2000.

Dilla, Sumadi. (2007). Komunikasi Pembangunan (Pendekatan Terpadu). Bandung: Simbiosa Rekatama Media.

Effendy, Onong Uchyana. (2004). Dinamika Komunikasi. Bandung. Remaja Rosdakarya.

Goad, T.W. (1982). Delivering Effective Training. San Diego: University Associate.

Harun, Rochajat dan Elvinaro Naro. (2011). Komunikasi Pembangunan dan Perubahan Sosial (Perspektif Dominan, Kaji Ulang, dan Teori Kritis). Jakarta: Rajawali Press.

Holmes, David. (2012). Teori Komunikasi (Media, Teknologi, Masyarakat). Yogyakarta: Pustaka Pelajar.

Iriantara, Yosal. (2009). Literasi Media (Apa, Mengapa, Bagaimana). Bandung: Simbiosa Rekatama Media.

Kindervatter, S. (1979). Nonformal Education as an Empowering Process with Case Studies in Indonesia and Thailand. Amherst, Mass: Center For International Education University of Massachusetts. 
Marhaeni. Dwi Pangastuti. (2016). "Revitalisasi Komunikasi Tradisional Pada Era Globalisasi”. ISKI 1 (Oktober). Hal 59-63.

Moss, Sylvia, \& Stewart. L. Tubbs (2005). Human Communication (KonteksKonteks Komunikasi). Bandung: Rosdakarya.

Nadler, L. (1982). Designning Training Programs: The Critcal Events Model. Reading, Mass: Addison-Wesley Publishing Company.

Nasution. Zulkarimen. (2009). Komunikasi Pembangunan Pengenalan Teori Dan Penerapan. Jakarta. Raja Grafindo Persada.

Paramita, Sinta. (2015). "Makalah Komunikasi Pembangunan Berbasis Teknologi Di Desa Wisata Sri Gethuk Yogyakarta.” ISKI. 1 (Oktober). Hal.235-252.

Parker, E.B., dan Donald A. Dunn. (1972). Information Technology: Its Social Potential Science. Dalam Werner J. Severin dan James W. Tankard, Jr. 2005.

Ruyle, K.E. (1995) “Group Training Methods (Detailed)” dalam Kelley, L. (ed). 1995. The ASTD Technical and Skills Training Handbook. New York, N.Y: McGraw-Hill,Inc.

Stole, V. (2001). Mancraft Training Model. Kristiandsand: Agder Research Foundation.

Sudarmanto. (2015). Kinerja dan Pengembangan Kompetensi SDM (Teori, Dimensi Pengukuran, dan Implementasi dalam Organisasi). Yogyakarta: Pustaka Pelajar.

Sugiana, Dadang. (2016) Pembelajaran Transformatif Berbasis Komunikasi Kunci Sukses Proses Pembelajaran di Perguruan Tinggi. Orasi Ilmiah Dies Natalis ke-56 Fikom Unpad, (September). Hal.7

Sulistyastuti, Dyah Ratih. (2007) "Jurnal Pembangunan dan MDGs di Indonesia: Sebuah Refleksi Kritis.” Jurnal Kependudukan Indonesia. Vol. II, No. 2, 2007.

Tilaar. HAR. (1990). Pendidikan Dalam Pembangunan Nasional Menyongsong Abad XXI, Jakarta Balai Pustaka.

Yusuf, Pawit Muhammad. (2010). Komunikasi Instruksional (Teori dan Praktik). Jakarta: Bumi Aksara.

Winoto. Yunus. 2004. Penerapan kurikulum Berbasis Kompetensi (Competency base Curiculum) Pada Pendidikan Ilmu Perpustakaan. Jurnal Komunikasi dan Informasi. Fikom Unpad .Volume 3 No 1. Halaman (196 : 2007),

Website:

Nasution, Reza.A, "Transformative Learning dan Case Based Learning” dalam http://www.sbm.itb.ac.id/id/transformative-learning-dan-case-basedlearning.

Pramono, Gatot. Sekilas Computer Mediated Communication dan Perannya Dalam Pendidikan Jarak Jauh. UPT Perpustakaan Digital Universitas Negeri Malang. dalam http://library.um.ac.id/majalah/printmajalah.php/108.html. 